\title{
Assessing properties of Acantholippia deserticola (phil.) moldenke essential oil: Comparison between hydrodistillation and microwave-assisted hydrodistillation extraction methods
}

\author{
Jenifer Palma ${ }^{1}$, Ana Mercado ${ }^{2}$, Adrian Paredes ${ }^{3}$, Catherine Lizama ${ }^{4}$, Gissel Pohl ${ }^{1}$, Maria J. Larrazabal ${ }^{1, *}$ \\ ${ }^{1}$ Departamento de Ciencias de los Alimentos y Nutrición, FACSA, Universidad de Antofagasta, Antofagasta, Chile; \\ ${ }^{2}$ Departamento de Biotecnología, FACIMAR, Universidad de Antofagasta, Antofagasta, Chile; ${ }^{3}$ Instituto Antofagasta, \\ Laboratorio Química Biológica, Universidad de Antofagasta, Antofagasta, Chile; ${ }^{4}$ Departamento de Tecnología Médica, \\ Universidad de Antofagasta, Antofagasta, Chile
}

* Corresponding Author: Maria J. Larrazabal, Departamento de Ciencias de los Alimentos y Nutrición, Universidad de Antofagasta, Avenida Angamos 601, Antofagasta 1240000, Chile. Email: maria.larrazabal@uantof.cl

Received: 24 July 2020; Accepted: 07 September 2020; Published: 31 October 2020

(C) 2020 Codon Publications

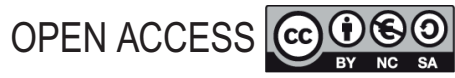

ORIGINAL ARTICLE

\begin{abstract}
Acantholippia deserticola (Rica-Rica) is a native shrub of the Chilean highlands used as a medicinal plant and food dressing. The objective of this study was to compare the physical, antioxidant and antimicrobial characteristics of its essential oil (EO), based on the process parameters and extraction methods using hydrodistillation (HD) and microwave-assisted hydrodistillation (MAHD), and assessing presence of fatty acids. The process performance as well as the colour parameters, refractive index, fatty acid profile, antioxidant activity and antimicrobial activity were evaluated. The best process conditions for HD were $90 \mathrm{~min}, 420 \mathrm{~W}$ and $150 \mathrm{~g} 1000 \mathrm{~mL}^{-1}$; for MAHD, these were $90 \mathrm{~min}, 700 \mathrm{~W}$ and $200 \mathrm{~g} 1000 \mathrm{~mL}^{-1}$, with yields of 0.45 and $0.49 \mathrm{~mL} 100 \mathrm{~g}^{-1}$ and antioxidant capacities of 2.38 and $3.92 \mu \mathrm{mol}$ Trolox $\mathrm{g}^{-1}$ respectively. The collection season, extraction method and its parameters affected the yield and fatty acid profile, influencing EOs' activity. In terms of mass of herbs, process time as well as energy efficiency and environmental impact, the extraction of MAHD was 8\% more efficient. EOs extracted by both methods show a slight inhibitory effect on Streptococcus sp. and Bacillus cereus, and MAHD EO showed a highly inhibitory effect on Streptococcus Group A. The type of extraction method and the process parameters could be set to obtain suitable EOs according to its potential industrial application.
\end{abstract}

Keywords: antimicrobial; antioxidant; fatty acids; Rica-Rica; yield

\section{Introduction}

Essential oils (EOs) are complex mixtures of organic substances, which are liquid at room temperature and contain volatile compounds. They are generally soluble in organic solvents, low soluble in water and can be obtained from the roots, stems, leaves and flowers of plants (El Asbahani et al., 2015). The properties of EOs, which depend on their composition, include antibacterial (Deng et al., 2016), antifungal (Falasca et al., 2016), anti-inflammatory (Rodrigues et al., 2016) and antioxidant (Sodeifian and Sajadian, 2017) effects. These properties allow EOs to be used in different fields (El Asbahani et al., 2015) such as the food industry (Atarés and Chiralt, 2016), in sanitising products (Falcó et al., 2018) or as pesticides (Benites et al., 2014; Zarria et al., 2010). EOs are products of agricultural industry and have great prospects for the future development. Traditional methods used for the extraction of EOs from plants include steam distillation (Périno-Issartier et al., 2013), hydrodistillation (HD) (Jiao et al., 2012; Li et al., 2012; 
Stanojević et al., 2015) and solvent extraction (Soran et al., 2009). New extraction methods favour green technologies, with a focus on reducing environmental impacts while improving energy efficiency (Chemat et al., 2012; Farhat et al., 2017). These methods include microwave-assisted hydrodistillation (MAHD) (Ajayi et al., 2016; Fardhyanti et al., 2019; Golmakani and Moayyedi, 2015; Jeyaratnam et al., 2016), ultrasound extraction (Hashemi et al., 2018), solvent-free extraction (Kusuma et al., 2018), supercritical fluid extraction (Shahsavarpour et al., 2017; Sodeifian and Sajadian, 2017) and ohmic-assisted HD (Gavahian et al., 2015), among others. The extraction methods of EO differ in their process parameters such as the size of particles (Shahsavarpour et al., 2017), the use of solvents (Okoh et al., 2010), the sample-solvent mass ratio and the time and power of the process (Kusuma et al., 2018). Several authors (Gavahian et al., 2015; Torres-León et al., 2017; Megawati et al., 2019) have reported that the MAHD method, which takes advantage of microwaves as a heat source in the extraction process, shows greater efficiency in comparison to HD. Taban et al. (2018) reported that the use of microwave energy to heat solvents produces a greater rupture of cells. Nazarni et al. (2018) agreed with this finding and noted that this breakage would facilitate the penetration of solvent into plant material, allowing the release of intracellular products, thereby accelerating mass transfer. However, fatty acids can be carried away during HD and present in EOs. This has been poorly studied (Rezaei et al., 2018; Zaïri et al., 2019), although fatty acids have interesting nutritional and bioactive properties (Koç et al., 2019; Ohlrogge et al., 2018).

Acantholippia deserticola (Rica-Rica [RR]) is an aromatic herb native to the Chilean highlands and used in the form of a decoction or infusion because of its medicinal properties and as a food dressing. Indeed, a number of Acantholippia species have been used in popular medicines for analgesic and anti-inflammatory effects (Díaz-Véliz and Mora, 2012; Larrazabal et al., 2018). Rica-Rica is registered as a medicinal herb by the Chilean Ministry of Health (Parada, 2012), and its hydroalcoholic extracts have shown antioxidant (Morales et al., 2008) and anti-inflammatory (Carro et al., 2015) effects. Its phytochemical compounds include flavonoids, tannins, saponins and triterpenes/steroids that could be potentially toxic to cellular systems at concentrations of 50-100 $\mu \mathrm{g} / \mathrm{mL}$ (Carro et al., 2015). Rojo et al. (2009) and Sampietro et al. (2016) agree that the main compound of Rica-Rica EO (RR-EO), obtained by the HD method, is $\beta$-thujone, and the two studies found its contents to be $77.9 \%$ and $66.5 \%$, respectively. However, the studies differed in the second highest compound, which was found to be $\alpha$-thujone (10.5\%) and trans-sabinyl acetate $(12.1 \%)$, respectively. These compositional differences could be attributed to geographic, climatic, seasonal or other environmental factors, and these differences can affect the biological activity of RR-EO (Falasca et al., 2016; Gasparetto et al., 2017). Benites et al. (2013) extracted EOs by the HD method and reported sedative, anxiolytic and antidepressant effects. Rojo et al. (2006) did not find any antimicrobial activity against Staphylococcus aureus, Escherichia coli or Candida albicans. It was previously demonstrated that RR-EO extracted by MADH has antioxidant activity, showed strong inhibition against food-associated pathogenic bacteria and contained 13 compounds, being $\beta$-thujone (45\%) the main compound (Larrazabal et al., 2019). However, it is necessary to characterise whether different methods of extraction of EOs change their physical and biological properties.

The objective of this study was to evaluate the effect of the extraction process parameters (time, power and herb:water ratio) on the yield and energy efficiency of the process, physical characteristics (colour parameters and refractive index $[R I]$ ), presence of fatty acids and biological activity (antioxidant and antimicrobial) of EOs when extracted by HD and MAHD methods.

\section{Materials and Methods}

\section{Sample collection}

Acantholippia deserticola (Rica-Rica) leaves and stems were collected from the Toconao locality within the San Pedro de Atacama community $\left(22.9087^{\circ} \mathrm{S}, 68.1997^{\circ} \mathrm{W}\right)$ of the Antofagasta region, Chile. Samples were collected in two stages, September (stage I) and January (stage II); these months, which correspond to the austral spring and summer respectively, were selected to evaluate the impact of season on EO composition. Moisture (g water

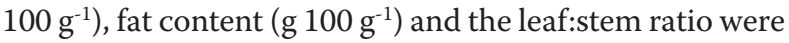
determined for stage I and II samples. The herbs were authenticated and registered by Dr. Roberto Rodríguez, Department of Botany, School of Natural Sciences and Oceanography, University of Concepción (Universidad de Concepción), Chile, under specimen number CONC 182473 .

\section{EO extraction}

\section{Stage I}

The stage I samples were used to evaluate the effect of the process parameters of each extraction method (HD and MAHD) on the yield and EO characteristics. For HD extraction, the samples were distilled using a Clevenger apparatus equipped with a heating blanket. For MAHD extraction, a microwave (Model MS-1948 JL, LG) was used following the methodology described by Golmakani and Moayyedi (2015) and Ferhat et al. (2006). The methodology consists of introducing a flask, with the 
sample and water as appropriate for each treatment, into a microwave oven modified for this purpose, as seen in Figure 1. In both cases, a $2^{3}$ factorial experimental design was used, where the effects of time, 90-120 min (HD) and 45-90 min (MAHD); heating potency, 240-420 W (HD) and 420-700 W (MAHD); and herb:water ratio, (120-200 g $\left.1000 \mathrm{~mL}^{-1}\right)$, were evaluated. To project the future industrial applications of these extraction processes, energy density (ED) was determined for each of the treatments evaluated. Depending on the mass of herb and water (g) and the power used (W), the ED varied between 0.200 and $0.365 \mathrm{~W} \mathrm{~g}^{-1}$ for HD and between 0.350 and $0.609 \mathrm{~W} \mathrm{~g}^{-1}$ for MAHD.

The extracted EOs were separated from the aqueous layer using sodium sulphate, filtered, and recovered with ethyl ether before finally heated at $40^{\circ} \mathrm{C}$ for $1 \mathrm{~h}$ in an oven (BOV-V-125F, Biobase). For both extraction methods,

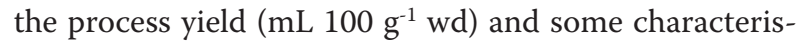
tics of EO, such as the colour parameters $\left(\mathrm{L}^{\prime \prime}, \mathrm{a}^{\prime \prime}\right.$ and $\left.\mathrm{b}^{\prime \prime}\right)$, RI, antioxidant capacity (AC) and fatty acid profile (GC), were evaluated using dried samples $\left(30^{\circ} \mathrm{C}\right.$ for $\left.48 \mathrm{~h}\right)$. The results were expressed on a dry basis. For each extraction method (HD and MAHD), the process parameters that showed the greatest yield and AC were selected.

\section{Stage II}

The stage II samples were used to: (i) evaluate the effect of harvesting season on extraction performance and EO characteristics, and (ii) preliminarily evaluate the EO antibacterial activity and determine the energy efficiency of the extraction process of HD and MAHD methods, according to the parameters selected in stage I. The same analyses that were used in stage I were carried out; in addition, antimicrobial activities against 32 pathogenic bacteria were also determined.

\section{Analytical methods}

\section{Physical parameters}

The RI was measured according to the Food Chemical Codex (FCC, 1996) at $20^{\circ} \mathrm{C}$. The colour parameters, $\mathrm{L}^{\prime \prime}$, $\mathrm{a}^{\text {" and }} \mathrm{b}$, were measured using a Colorflex Tristimulus Color Plot (Model 11491, Hunter Lab).

\section{Presence of Fatty acid}

Presence of fatty acid was determined using a Shimadzu GC-2010 gas chromatographer with the Supelco 37 Component FAME Mix as the standard and an RTX-225 column $(30 \mathrm{~m} \times 0.32 \mathrm{~mm}$ I.D. $\times 0.2 \mu \mathrm{m}$; $90 \%$ biscyanopropyl $/ 10 \%$ phenylcyanopropyl polysiloxane). An initial oven temperature of $120^{\circ} \mathrm{C}$ was maintained for 2 min before increasing by $4^{\circ} \mathrm{C}$ every 2 min until reaching $230^{\circ} \mathrm{C}$. The nitrogen carrier gas flow was $19.9 \mathrm{~cm} \mathrm{~s}^{-1}$, while sample injection was $1 \mu \mathrm{L}$ (splitless analysis). The methodology described by Folch et al. (1957) was used for fatty acid methylation.

\section{Antioxidant capacity}

The AC was determined via the ferric ion reducing antioxidant power assay (FRAP) using acetone as the solvent and Trolox as the standard. The calibration curve standards (between 10 and $80 \mu \mathrm{M}$ ) and the samples were measured at $593 \mathrm{~nm}$ at $4 \mathrm{~min}$ after the start of the reaction.

\section{Antimicrobial activity}

The antimicrobial activity was assessed using the paperdisc agar-plate method. The following 21 Gram-negative bacteria were assessed: Enterobacter aerogenes, Citrobacter freundii, Klebsiella oxytoca, Providencia alcaligenes, Pseudomonas fluorescens, Pseudomonas putida, Pseudomonas aeruginosa, Acinetobacter sp., Aeromonas hydrophila, Aeromonas veronii, Yersinia enterocolitica, Serratia rubidaea, Salmonella typhi, Salmonella paratyphi B, Shigella flexneri, Klebsiella pneumoniae, Escherichia coli, Vibrio cholerae, Proteus vulgaris, Proteus mirabilis, Alcaligenes sp. and Vibrio alginolyticus. The following 10 Gram-positive bacteria were assessed: Staphylococcus epidermidis, Listeria monocytogenes, Corynebacterium sp., Bacillus cereus, Enterococcus sp., Staphylococcus aureus, Enterococcus sp., Streptococcus Group A, Micrococcus sp., Streptococcus sp., and the yeast fungus Candida sp. Strains were obtained from the collection of Departamento de Tecnología Médica of Universidad de Antofagasta, Chile, and clinical isolates were kept in a cepary at $-20^{\circ} \mathrm{C}$ in medium with $20 \%$ glycerol and in a cepary with BrainHeart Agar medium at room temperature. Müller-Hinton agar medium (20 mL; Liofilchem) was poured onto petri dishes, and the cultured bacteria $(100 \mu \mathrm{L})$ were plated at an approximate final concentration of $10^{6}$ bacteria $\mathrm{mL}^{-1}$. After $15 \mathrm{~min}$, a Whatman No. 1 paper disc $(6 \mathrm{~mm}$; Whatman International) impregnated with the EO $(10 \mu \mathrm{L})$ was placed on the agar surface. The plates were incubated at $37^{\circ} \mathrm{C}$ for $24 \mathrm{~h}$ and the inhibition diameter was measured. All analyses were performed in duplicate.

\section{Statistical analysis}

Analysis of variance was applied using Statgraphics Centurion software to compare the characteristics of the oils obtained according to the collection time, the process parameters (time, temperature, power and herb:water ratio) and the extraction method.

\section{Results and Discussion}

\section{Raw material}

While both sample groups presented a stem:leaf mass ratio close to 70:30 (Table 1), the stage II specimens 
(January, austral summer) had significantly higher humidity and fat contents than those from stage I (September, austral spring). Notably, between January and March, the north Chilean highlands undergo a climatological phenomenon known as the 'highland winter', which is characterised by heavy rains over the semiarid soil. Several authors have evidenced a strong relationship between the climatological conditions that are present at the time of collection and the yield of the extracted EO. Sá et al. (2016) and Gasparetto et al. (2017) reported higher EO yields from plants harvested in the months that had the highest rainfall, that is, between December and March. Furthermore, Gasparetto et al. (2017), together with Falasca et al. (2016), reported important seasonal effects on the composition of oils and their biological properties. In this work, the highest fat content was obtained from the plants collected in stage II, coinciding with the summer raining period, having EO yields that were approximately three times higher than those collated in stage I.

\section{Stage I: Evaluation of HD and MAHD extraction conditions}

\section{HD method}

The physical and biological EO properties extracted with the HD method are shown in Figure 1. In terms of the colour parameters, L" values (Figure 2A) were markedly low (close to zero), meaning that the EOs were very dark, and the $\mathrm{a}^{*}$ and $\mathrm{b}^{*}$ coordinates (Figure 2B) were near to the axes of the CIELAB colour sphere. This implies very low colour saturation, close to achromaticity. Treatments with a lower power $(240 \mathrm{~W})$ produced a more greenish tone $\left(\mathrm{a}^{*}<0\right)$, while the EOs obtained with a greater power level had redder tones $\left(\mathrm{a}^{*}>0\right)$. The $\mathrm{a}^{*}$ value was significantly affected in a directly proportional way by the time and power factors $(P<0.05)$. The other colour parameters, $L^{*}$ and $b^{*}$, and the RI, were not significantly affected by any of the factors (time, power and herb:water ratio) or their interactions $(P>0.05)$. The RI (Figure $2 C$ ) was between 1.451 and 1.453 , values within the characteristic intervals reported for other herbal EOs (Gavahian et al., 2015; Torrenegra et al., 2015; Ud-Daula et al., 2016). The highest RI values were obtained when a larger amount of sample mass was used.
Extraction with HD, using a factorial design of $2^{3}$, pre-

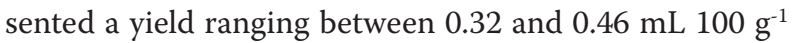
(Figure 2D). The yield was significantly higher $(P<0.05)$ in the treatments with a greater power (red figures) and a lower herb mass (empty figures). The latter finding was consistent with that reported by Stanojević et al. (2015), who demonstrated that by increasing the amount of water with respect to the mass, or in this case at a lower herb:water ratio, the resistance to the transfer of mass was reduced and the contact of sample with water was improved, promoting extraction. Regarding the extraction time, in most of the cases the yields were increased in the treatments with longer extraction period $(P>0.05$, square figures), which was probably related to a higher degree of warming that favoured the transfer of mass (Li et al., 2012). The same phenomenon can explain the effect of power on yield. On the other hand, at lower power (blue figures), the process time increased the EO's AC, probably because of greater extraction of the compounds responsible for this activity. However, at high power levels (red figures), the opposite effect occurred. In such cases, the thermal degradation of those compounds could have occurred. In particular, an intense and/or prolonged thermal treatment may be responsible for a significant loss of natural antioxidants because most of these compounds are relatively unstable (Tomaino

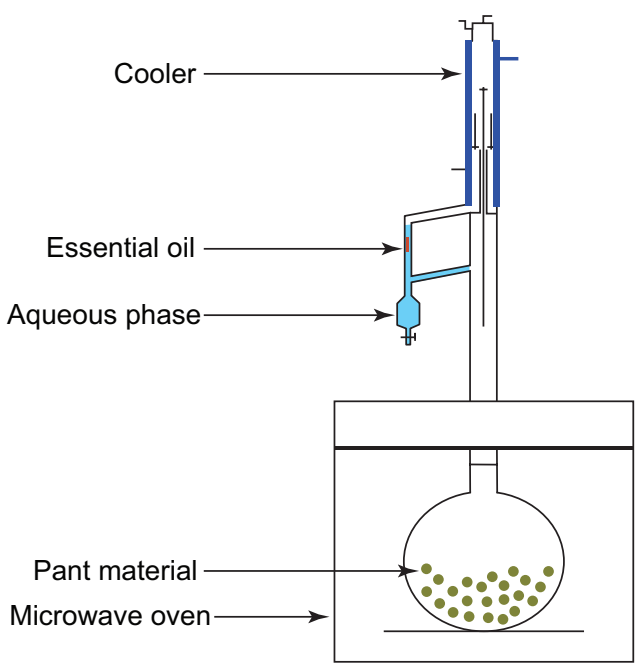

Figure 1. Microwave-assisted hydrodistillation (MAHD) method (Ferhat et al. 2006).

Table 1. Herb samples' characterisation.

\begin{tabular}{|c|c|c|c|c|c|}
\hline Stage & Period & Stem* $(\%)$ & Leaf* $(\%)$ & Humidity (\%) & Fat (\%) \\
\hline 1 & September (Spring) & $70 \pm 2$ & $30 \pm 2$ & $11.7 \pm 0.1$ & $0.37 \pm 0.28$ \\
\hline$\|$ & January (Summer) & $71 \pm 2$ & $29 \pm 2$ & $17.1 \pm 0.1$ & $1.14 \pm 0.10$ \\
\hline
\end{tabular}




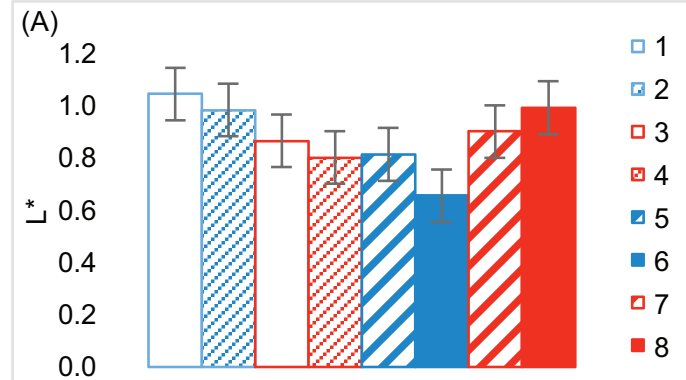

(C)

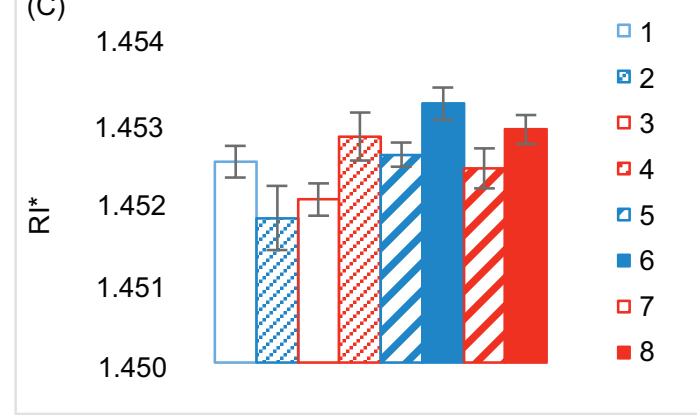

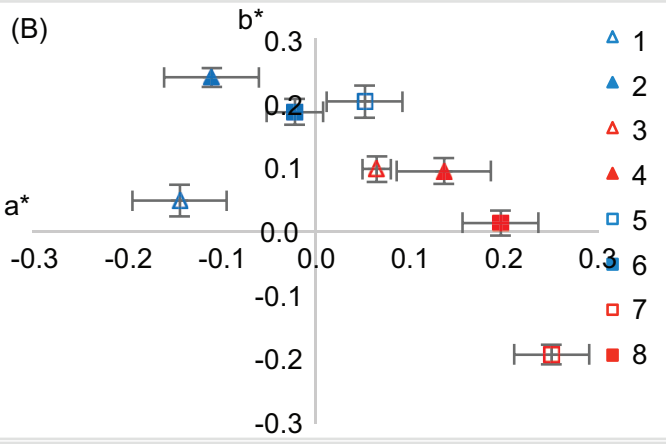

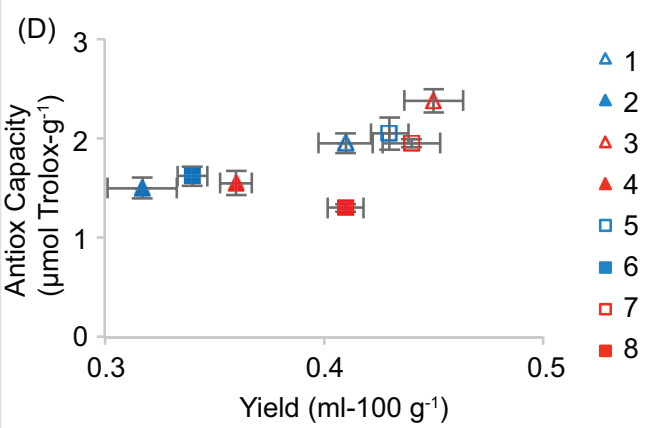

Figure 2. Colour parameters $L^{*}(A)$, a and $b^{*}(B)$, refractive index (RI; $\left.C\right)$ and antioxidant capacity and yield (D) of Rica-Rica essential oil obtained through hydrodistillation (HD) for each treatment (1: $90 \mathrm{~min} 240 \mathrm{~W} 150 \mathrm{~g} ; 2: 90 \mathrm{~min} 240 \mathrm{~W} 200 \mathrm{~g} ; 3: 90 \mathrm{~min}$ 420 W $150 \mathrm{~g} ; 4: 90 \min 420 \mathrm{~W} 200 \mathrm{~g} ; 5: 120 \mathrm{~min} 240 \mathrm{~W} 150 \mathrm{~g} ; 6: 120 \min 240 \mathrm{~W} 200 \mathrm{~g} ; 7: 120 \min 420 \mathrm{~W} 150 \mathrm{~g}$; and 8: $120 \min 420$ W $200 \mathrm{~g})$.

et al., 2005). Similar to the observations of process parameters on yield, the herb mass was found to exert an inverse effect on AC. Although treatments 3 and 7, both with the lowest herb mass and the highest potency, presented similar yields, treatment 3 (shorter period) had a greater AC. Apparently, with this treatment, most of the antioxidant compounds could be extracted, reducing the thermal degradation that could occur under longer periods. Tomaino et al. (2005), and Olmedo et al. (2015) reported that the thermal stability of the antioxidant activity of EOs depends on their composition. While for some EOs, the AC may decrease due to thermal heating, in other cases this property is not affected or may even increase due to greater extraction or transformation of responsible compounds.

More than $70 \%$ of the extracted fatty acids were saturated (Table 2), and the main fatty acid was caprylic acid (C8:0), which has been reported to have antifungal, antibacterial and antiviral effects (Gadotti et al., 2014; Ruiz-Rico et al., 2015). In turn, the main component of monounsaturated fatty acids was palmitoleic acid (C16:1), followed by elaidic acid (C18:1n9t). Beneficial biological effects have been reported for palmitoleic acid, related to improved hyperglycaemia and hypertriglyceridemia (Yang et al., 2011). Elaidic acid, the trans isomer of oleic acid, could be formed due to the heating process during EO extraction (Valenzuela, 2008a, 2008b). Also among the polyunsaturated fatty acids (PUFAs) was linolelaidic acid (C18:2n6t), the trans isomer of linoleic acid, which appeared only when longer treatment period was used. This finding coincides with that of Bhardwaj et al. (2016) regarding the generation of trans isomers in intense technological processes applied to oils. In treatments with lower power levels, no PUFAs were detected. This could be explained by the lower heating intensity sufficient for their extraction. While the EO AC of some species can decrease due to thermal heating, in other species this property is not affected by heating. This is a crucial point to consider when assessing possible applications, particularly for the food industry.

\section{MAHD method}

The colour parameters of EOs extracted by the MAHD method were similar to those obtained by the HD method. The L'values (Figure $3 \mathrm{~A}$ ) were close to 0 (i.e. the EOs were dark), and the $\mathrm{a}^{\circ}$ and $\mathrm{b}^{\prime \prime}$ coordinates (Figure 3B) were near to both axes; however, in the MAHD extraction, all the values of a" were positive, implying that these EOs were more brown than greenish. No significant effects were found for the herb:water ratio, time and power, or their interactions. The RI (Figure 3C) for MAHD varied between 1.452 and 1.453 , which is within the ranges reported for other EOs obtained through 
Table 2. Fatty acids profile for Rica-Rica essential oil obtained through hydrodistillation treatment (1: $90 \mathrm{~min} 240 \mathrm{~W} 150 \mathrm{~g} ; 2: 90 \mathrm{~min} 240 \mathrm{~W}$ $200 \mathrm{~g} ; 3$ : $90 \mathrm{~min} 420 \mathrm{~W} 150 \mathrm{~g} ; 4: 90 \mathrm{~min} 420 \mathrm{~W} 200 \mathrm{~g} ; 5: 120 \mathrm{~min} 240 \mathrm{~W} 150 \mathrm{~g} ; 6: 120 \min 240 \mathrm{~W} 200 \mathrm{~g} ; 7: 120 \min 420 \mathrm{~W} 150 \mathrm{~g}$ and 8: $120 \mathrm{~min}$ $420 \mathrm{~W} 200 \mathrm{~g}$ ).

\begin{tabular}{|c|c|c|c|c|c|c|c|c|}
\hline \multirow[t]{2}{*}{ Fatty acids } & \multicolumn{8}{|c|}{ Treatment (\%) } \\
\hline & 1 & 2 & 3 & 4 & 5 & 6 & 7 & 8 \\
\hline C8:0 & $70.2 \pm 0.1^{\mathrm{bcd}}$ & $75.3 \pm 0.2^{d}$ & $65.1 \pm 2.7^{b}$ & $71.3 \pm 0.8^{\mathrm{cd}}$ & $70.2 \pm 0.2^{\mathrm{cd}}$ & $68.2 \pm 1.3^{\mathrm{bc}}$ & $58.2 \pm 5.4^{\mathrm{a}}$ & $67.1 \pm 0.9 \mathrm{bc}$ \\
\hline $\mathrm{C} 12: 0$ & - & - & - & - & - & - & - & $1.1 \pm 0.8^{\mathrm{a}}$ \\
\hline $\mathrm{C} 16: 0$ & $6.1 \pm 0.6^{\mathrm{bc}}$ & $5.1 \pm 0.3^{b}$ & $10.1 \pm 0.4^{\mathrm{e}}$ & $8.1 \pm 0.3^{d}$ & $6.0 \pm 0.1^{\mathrm{b}}$ & $4.2 \pm 0.3^{\mathrm{a}}$ & $7.0 \pm 0.6^{c}$ & $6.3 \pm 0.2^{b}$ \\
\hline C16:1 & $8.2 \pm 1.0^{\mathrm{ab}}$ & $6.0 \pm 0.1^{\mathrm{a}}$ & $6.2 \pm 1.6^{\mathrm{a}}$ & $5.2 \pm 0.2^{\mathrm{a}}$ & $6.2 \pm 0.7^{\mathrm{a}}$ & $11.3 \pm 0.5^{b}$ & $7.1 \pm 3.3^{\mathrm{a}}$ & $7.1 \pm 0.2^{\mathrm{a}}$ \\
\hline C18:1n9t & $8.3 \pm 0.6^{a}$ & $6.2 \pm 1.4^{\mathrm{a}}$ & $6.2 \pm 3.4^{\mathrm{a}}$ & $4.1 \pm 0.2^{\mathrm{a}}$ & $5.4 \pm 0.5^{\mathrm{a}}$ & $4.1 \pm 0.5^{\mathrm{a}}$ & $8.2 \pm 4.2^{\mathrm{a}}$ & $5.4 \pm 1.4^{\mathrm{a}}$ \\
\hline C18:2n6t & - & - & - & - & $5.4 \pm 0.4^{\mathrm{a}}$ & $5.1 \pm 0.3^{a}$ & $5.2 \pm 0.0^{\mathrm{a}}$ & $5.3 \pm 0.1^{a}$ \\
\hline C21:0 & $4.2 \pm 0.3^{b c}$ & $3.1 \pm 0.2^{\mathrm{a}}$ & $5.2 \pm 0.5^{\mathrm{cd}}$ & $5.4 \pm 0.7^{\mathrm{cd}}$ & $4.3 \pm 0.3^{\mathrm{ab}}$ & $3.2 \pm 0.4^{\mathrm{a}}$ & $6.1 \pm 0.1$ & $4.1 \pm 0.3^{\mathrm{bc}}$ \\
\hline $\mathrm{C} 24: 1$ & $4.1 \pm 0.5$ & $5.0 \pm 0.5$ & $9.1 \pm 1.4$ & $7.1 \pm 0.7$ & $5.2 \pm 0.3$ & $4.0 \pm 0.2$ & $9.2 \pm 1.4^{\mathrm{d}}$ & $6.0 \pm 0.8$ \\
\hline Saturated & 80 & 83 & 79 & 84 & 80 & 76 & 71 & 78 \\
\hline Monounsaturated & 20 & 17 & 21 & 16 & 15 & 20 & 24 & 18 \\
\hline Polyunsaturated & - & - & - & - & 5 & 5 & 5 & 5 \\
\hline
\end{tabular}

Different superscript letters in columns indicate significant differences $(P<0.05)$.

(A)

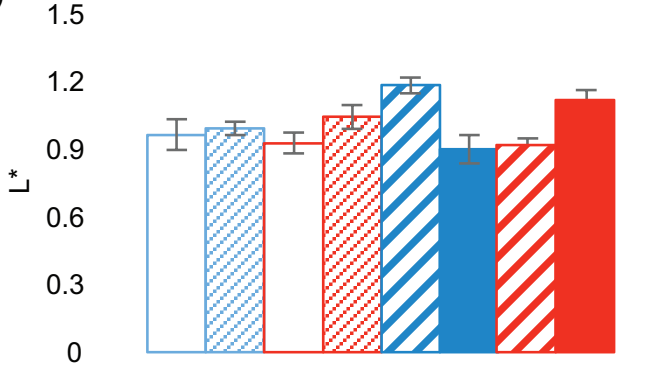

(C)

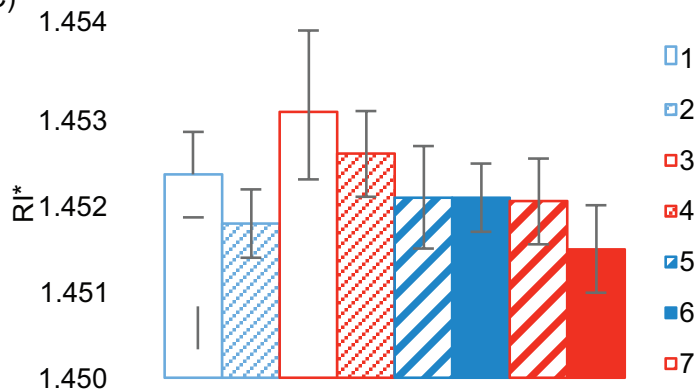

(B)

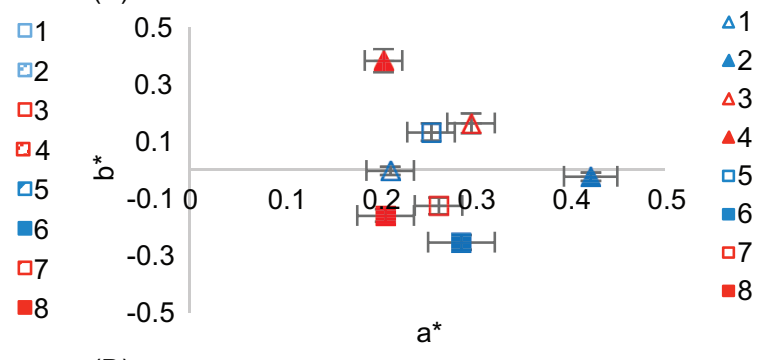

(D)

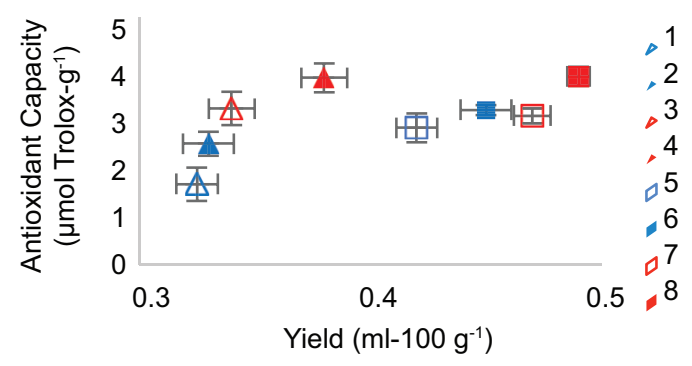

Figure 3. Colour parameters $L^{*}(A), a^{*}$ and $b^{*}(B)$, refractive index (RI; C) and antioxidant capacity and yield (D) of Rica-Rica essential oil obtained through microwave-assisted hydrodistillation (MAHD) for each treatment (1: $45 \mathrm{~min} 420 \mathrm{~W} 150 \mathrm{~g}$; $: 45 \mathrm{~min}$ $420 \mathrm{~W} 200 \mathrm{~g} ; 3: 45 \mathrm{~min} 700 \mathrm{~W} 150 \mathrm{~g} ; 4: 45 \mathrm{~min} 700 \mathrm{~W} 200 \mathrm{~g} ; 5: 90 \mathrm{~min} 420 \mathrm{~W} 150 \mathrm{~g} ; 6: 90 \mathrm{~min} 420 \mathrm{~W} 200 \mathrm{~g} ; 7: 90 \mathrm{~min} 700 \mathrm{~W} 150 \mathrm{~g}$; 8: $90 \min 700 \mathrm{~W} 200 \mathrm{~g}$ ).

this extraction method, for example 1.46 (oregano herb; Torrenegra et al., 2015) and 1.431 (Mentha piperita; Gavahian et al., 2015). There are no previous reports of A. deserticola EOs extracted using the MAHD method. Similar results were reported by Golmakani and Moayyedi (2015) who did not find a significant effect of either extraction method (HD or MAHD) on the colour coordinates or RI of EOs.

In this work, when the MAHD method was used, the yields varied between 0.31 and $0.49 \mathrm{~mL} 100 \mathrm{~g}^{-1}$ (Figure 3D), which were higher than those obtained by 
the HD method (shown previously). The higher yields resulted from the higher extraction rates enabled by microwaves and could be due to a synergy of two transfer phenomena, mass and heat (Golmakani and Moayyedi, 2015). The microwave energy increases the molecular movement, thus improving the penetration of solvent, which favours extraction of EO from biological matrix (Torres-León et al., 2017). All factors evaluated in the MAHD method (time, mass and power) were directly related to higher yields.

The AC varied between 1.68 and $3.89 \mu$ mol Trolox $100 \mathrm{~g}^{-1}$ and directly depended on the mass of the sample and the power used $(P<0.05)$. The time factor caused a greater increase in AC when lower power levels were used. The highest antioxidant capacities were achieved with treatment 4 (45 min) and treatment 8 (90 $\mathrm{min})$; however, the highest yield was also obtained with the latter. The longer process time used in this case promoted increased EO extraction, but, apparently, it did not contribute to increase in AC. This coincides with the findings of Jiao et al. (2012), who suggested a maximum power of 700 W which allowed the complete extraction of EO while avoiding the loss of volatile compounds.

The fatty acid profiles of the RR-EOs obtained through MAHD (Table 3) revealed a significantly higher proportion of saturated fatty acids (84-93\%) than of monounsaturated fatty acids (6-15\%). Interestingly, PUFAs were not detected in any of the eight treatments, in contrast to the findings when using traditional HD (see Table 2). Of the saturated fatty acids, caprylic acid (C8:0) was the most abundant (69\%), while among monounsaturated fatty acids, elaidic acid was the most abundant (4-12\%). The conditions of the MAHD process affected both type of fatty acids and their concentrations in EOs. Therefore, a critical factor worth evaluating is the optimal conditions for extracting certain fatty acids. As mentioned above, PUFAs were only obtained by the HD method after $120 \mathrm{~min}$. Shorter extraction periods but higher power levels are used in the MAHD method than used in the HD process. The absence of PUFAs in the EOs extracted by MAHD could be due to (i) a short extraction time that is insufficient to promote the transfer of compounds such as PUFAs from the plant tissue to water (Kusuma et al., 2018), (ii) harsher treatment conditions that degrade PUFAs during extraction (Bhardwaj et al., 2016; Li et al., 2012; Valenzuela, 2008a, 2008b) and (iii) compounds having a low interaction with microwaves, resulting in less extraction by MAHD than by HD (Orio et al., 2012). Because the yield and AC were higher in the MAHD method, it is unlikely that the process time was insufficient to extract PUFAs; therefore, it is considered more likely that their absence is caused by thermal degradation.

\section{Stage II: Comparative analysis of HD and MAHD}

\section{Yield and AC}

The process parameters for each technique were selected based on the best performance and AC obtained in stage 1. These were treatment 3 for HD (90 min, 420

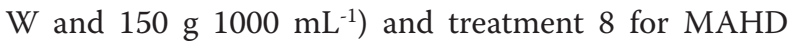

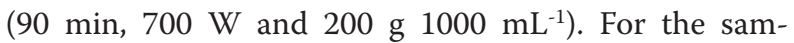
ples collected in stage I (spring), the AC was $2.38 \mu \mathrm{mol}$

Table 3. Fatty acids profile for Rica-Rica essential oil obtained through microwave-assisted hydrodistillation treatment (1:45 min $420 \mathrm{~W}$ $150 \mathrm{~g} ; 2: 45 \mathrm{~min} 420 \mathrm{~W} 200 \mathrm{~g} ; 3: 45 \mathrm{~min} 700 \mathrm{~W} 150 \mathrm{~g} ; 4: 45 \min 700 \mathrm{~W} 200 \mathrm{~g} ; 5: 90 \min 420 \mathrm{~W} 150 \mathrm{~g} ; 6: 90 \mathrm{~min} 420 \mathrm{~W} 200 \mathrm{~g} ; 7: 90 \mathrm{~min} 700 \mathrm{~W}$ $150 \mathrm{~g} ; 8: 90 \mathrm{~min} 700 \mathrm{~W} 200 \mathrm{~g}$ ).

\begin{tabular}{|c|c|c|c|c|c|c|c|c|}
\hline \multirow[t]{2}{*}{ Fatty acids } & \multicolumn{8}{|c|}{ Treatment (\%) } \\
\hline & 1 & 2 & 3 & 4 & 5 & 6 & 7 & 8 \\
\hline Caprylic acid (C8:0) & $82.1 \pm 0.0^{f}$ & $79.2 \pm 4.0^{\text {de }}$ & $69.1 \pm 0.0^{\mathrm{a}}$ & $71.2 \pm 0.1^{\mathrm{ab}}$ & $73.2 \pm 0.2^{b c}$ & $76.1 \pm 1.7^{c d}$ & $78.3 \pm 1.4^{\mathrm{de}}$ & $81.4 \pm 0.1^{\text {ef }}$ \\
\hline $\begin{array}{l}\text { Undecanoic acid } \\
\text { (C11:0) }\end{array}$ & $11.3 \pm 0.7^{c}$ & $7.2 \pm 0.7^{b}$ & $11.1 \pm 0.0^{c}$ & $12.3 \pm 1.1^{c}$ & $7.1 \pm 0.7^{b}$ & $4.4 \pm 2.1^{\mathrm{a}}$ & - & - \\
\hline Lauric acid (C12:0) & - & - & $2.2 \pm 0.0^{b}$ & - & $2.2 \pm 0.1^{b}$ & $2.0 \pm 0.0^{\mathrm{a}}$ & - & - \\
\hline $\begin{array}{l}\text { Palmitoleic acid } \\
\text { (C16:1) }\end{array}$ & - & - & - & - & - & $6.2 \pm 0.3^{a}$ & - & - \\
\hline $\begin{array}{l}\text { Elaidic acid } \\
\text { (C18:1n9t) }\end{array}$ & $7.1 \pm 0.7^{a b}$ & $13.1 \pm 6.7^{b}$ & $8.3 \pm 0.0^{a b}$ & $8.3 \pm 0.3^{\mathrm{ab}}$ & $6.2 \pm 1.6^{a}$ & $4.2 \pm 0.1^{\mathrm{a}}$ & $5.1 \pm 0.0^{\mathrm{a}}$ & $5.0 \pm 0.8^{a}$ \\
\hline $\begin{array}{l}\text { Heneicosanoic acid } \\
\text { (C21:0) }\end{array}$ & - & $3.0 \pm 0.1^{a}$ & $4.2 \pm 0.0^{\mathrm{ab}}$ & $4.2 \pm 0.5^{\mathrm{a}}$ & $6.1 \pm 1.0^{c}$ & $5.1 \pm 0.4^{b c}$ & $6.2 \pm 0.9^{c}$ & $5.2 \pm 0.1^{c}$ \\
\hline Nervonic acid (C24:1) & - & - & $6.3 \pm 0.0^{\mathrm{a}}$ & $5.2 \pm 0.4^{a}$ & $6.2 \pm 0.4^{a}$ & $5.3 \pm 0.7^{a}$ & $10.4 \pm 0.5^{c}$ & $8.3 \pm 1.6^{b}$ \\
\hline Saturated & 93 & 88 & 86 & 87 & 88 & 85 & 84 & 87 \\
\hline Monounsaturated & 7 & 12 & 14 & 13 & 12 & 15 & 16 & 13 \\
\hline
\end{tabular}

Different superscript letters in rows indicate significant differences $(P<0.05)$. 
Trolox $\mathrm{g}^{-1}$ and $3.98 \mu \mathrm{mol}$ Trolox $\mathrm{g}^{-1}$ and the yield was 0.45 and $0.49 \mathrm{Ml} 100 \mathrm{~g}^{-1}$ for HD and MAHD methods, respectively. For the samples collected in stage II (summer), a

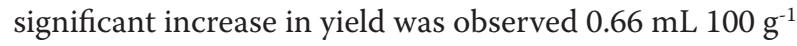
(HD) and $0.71 \mathrm{~mL} 100 \mathrm{~g}^{-1}$ (MAHD), while a slight reduction in AC was observed, $2.35 \mu$ mol Trolox $g^{-1}(\mathrm{HD})$ and $3.89 \mu \mathrm{mol}$ Trolox $\mathrm{g}^{-1}$ (MAHD). These results highlight two important points. The first is the effect of extraction method. In both stages, both yield and $\mathrm{AC}$ were higher with the MAHD technique. This could be explained as a combination of the following factors. (i) Power: the higher heating power used in MAHD can accelerate mass transfer to a certain extent, thus increasing the EO yield (Li et al., 2012); (ii) microwaves: these produce a greater rupture of plant tissues, which has been verified by scanning electron microscope (SEM; Farhat et al., 2017) and results in a more efficient heat flow affecting the release rate (Gavahian et al., 2015; Torres-León et al., 2017) and (iii) herb mass: 33\% more herb mass was used with this MAHD extraction. There is no complete agreement among authors on the extraction method (HD or MAHD) that demonstrates a greater performance. Some authors have found results similar to those obtained in this work, with yields significantly higher in the MAHD method, such as 0.92\% (MAHD) and 0.09\% (HD) for oregano EO (Torrenegra et al., 2015), among others (Jiao et al., 2012; Li et al., 2012). However, other studies, such as Ajayi et al. (2016), have reported 0.73\% for HD but only $0.64 \%$ for MAHD. Other authors report similar yields with both methods but with considerably shorter process period for the MAHD method (Bousbia et al., 2009; Gavahian et al., 2015). On the other hand, AC showed a significant increase in the EO obtained through MAHD compared to HD, which can be explained by the same factors-microwave energy, a greater power level (but at levels that do not reduce the content of antioxidant compounds) and higher herb:water ratios. The second important point highlighted by our results is the effect of the collection season. Differences were found in extraction process yield and the composition and properties of EOs. In one context, the higher yields obtained in stage II were directly related to the higher fat content of the samples collected in this stage (Table 1), and on the other side, the reduced $\mathrm{AC}$ observed for both techniques could be related to the compositional differences that occurred in the plants and therefore in their EO properties, depending on seasonality. Different authors have reported differences in yield, composition and properties, depending on seasonality. While de Alencar et al. (2017) and Delfine et al. (2017) reported a negative correlation between the rainy season or irrigation at the time of harvest and the EO yield, Moghaddam and Farhadi (2015) did not find any correlations. Jemâa et al. (2012) have found that the collection season in which the highest yield of eucalyptus is obtained also depends on the species. Regarding the relationship between EO properties and the collection season, de Alencar et al. (2017), and Jemâa et al. (2012), respectively, reported that antibacterial and fumigant activities were significantly higher in summer. Falasca et al. (2016) reported that in January they obtained the lowest EO performance and the best antifungal activity. Dhouioui et al. (2016) reported great variation in the amount of compounds present in EOs that depended on the month of collection; a significantly higher antimicrobial activity was found when the plants were collected in September. In the current work, the AC of samples collected in summer was slightly lower $(P>$ $0.05)$ than those of stage I. The reported differences in the water and fat composition of plants between the seasons could be an indicator that other compounds also vary over time, of which some could be related to AC.

\section{Colour parameters}

Regarding the colour parameters (Table 4), it was observed that in both collection seasons, and for both extraction methods, the EOs were markedly dark. Most EOs had yellow-orange tones, coinciding with the results of Delfine et al. (2017), but were extremely close to the axis, that is they were nearly achromatic. The only significant colour differences were for the $L^{*}$ values $(P<0.05)$; these where found in stage I, and the MAHD samples were lighter than the HD samples. In stage II, the opposite trend occurred. Notably, the colour properties are highly dependent on the composition of the analysed material.

\section{Fatty acid profile}

Important changes in the fatty acid profile were observed (Table 5) as a function of both the extraction method and

Table 4. Physical characteristics of Rica-Rica essential oils extracted through the selected conditions for traditional hydrodistillation and microwave-assisted hydrodistillation, with samples collected in stage II (summer).

\begin{tabular}{lcccc} 
& & Colour & & Refractive Index \\
\cline { 2 - 3 } & $\mathrm{L}^{*}$ & $\mathrm{a}^{*}$ & $\mathbf{b}^{*}$ & $\mathrm{nD}^{20}$ \\
$\mathrm{HD}$ & $0.60 \pm 0.00^{\mathrm{b}}$ & $0.12 \pm 0.10^{\mathrm{a}}$ & $0.49 \pm 0.20^{\mathrm{a}}$ & $1.453 \pm 0.100^{\mathrm{a}}$ \\
$\mathrm{MAHD}$ & $0.54 \pm 0.00^{\mathrm{a}}$ & $0.09 \pm 0.10^{\mathrm{a}}$ & $0.45 \pm 0.20^{\mathrm{a}}$ & $1.452 \pm 0.100^{\mathrm{a}}$ \\
\hline \\
$\begin{array}{l}\text { Different superscript letters in rows indicate significant differences }(\mathrm{P}<0.05) . \\
\mathrm{nD}\end{array}$
\end{tabular}


the collection season. Regarding the effect of extraction method, MAHD produced more saturated fats and a lower number of identified compounds than the HD method. When MAHD was applied, tridecanoic acid and palmitoleic acid were not detected, and the concentrations of caprylic acid, palmitic acid and elaidic acid were increased compared to HD. These differences are due to the use of different extraction techniques. Farhat et al. (2017), also reported fewer compounds obtained by MAHD than HD when extracting Rosmarinus officinalis L. In contrast, Ajayi et al. (2016) reported fewer compounds in EOs extracted from Cymbopogon citrates when HD was applied $(\mathrm{n}=7)$ compared to MAHD $(\mathrm{n}=16)$. Notably, other works have not reported considerable differences in the components of EOs, but differences have been found in the percentages of some compounds depending on the extraction method used (Li et al., 2012; Périno-Issartier et al., 2013). The present results coincide with those of previous studies that highlight the importance of considering component differences when selecting the optimal extraction method (Sodeifian and Sajadian, 2017). Regarding the effect of collection season, consistent with other authors (Dhouioui et al., 2016), EO compositional differences for both methods were observed between the collection periods. For the stage II samples (summer) and HD extraction, tridecanoic acid (C13:0) was found, but this compound was not detected in any of the stage I samples. In addition, although caprylic acid was still the principal fatty acid, its content was considerably reduced in both seasons and methods in stage II. In both stages and in all EOs there were a high proportion of saturated fatty acids. However, for stage II samples, an especial significant reduction was observed when the HD method was applied.

Table 5. Fatty acids profile for Rica-Rica essential oils extracted through traditional hydrodistillation and microwave-assisted hydrodistillation.

\begin{tabular}{lcc} 
Fatty acids & \multicolumn{2}{c}{$\%$} \\
\cline { 2 - 3 } & $\begin{array}{c}\text { HD } \\
\text { (treatment 3) }\end{array}$ & $\begin{array}{c}\text { MAHD } \\
\text { (treatment 8) }\end{array}$ \\
\hline Caprylic acid (C8:0) & $40.1 \pm 0.7^{\mathrm{a}}$ & $57.3 \pm 0.9^{\mathrm{b}}$ \\
Tridecanoic acid (C13:0) & $3.8 \pm 0.0$ & - \\
Palmitic acid (C16:0) & $15.4 \pm 1.2^{\mathrm{a}}$ & $19.4 \pm 0.5^{\mathrm{b}}$ \\
Palmitoleic acid (C16:1) & $10.7 \pm 0.2$ & - \\
Elaidic acid (C18:1n9t) & $15.6 \pm 1.0^{\mathrm{b}}$ & $7.3 \pm 0.0^{\mathrm{a}}$ \\
Heneicosanoic acid (C21:0) & $4.0 \pm 1.4^{\mathrm{a}}$ & $4.0 \pm 0.3^{\mathrm{a}}$ \\
Nervonic acid (C24:1) & $12.2 \pm 0.6^{\mathrm{a}}$ & $12.0 \pm 1.1^{\mathrm{a}}$ \\
Saturated & 60 & 80 \\
Monounsaturated & 40 & 20 \\
\hline Different superscript letters in columns indicate significant differences \\
(P<0.05).
\end{tabular}

\section{Antimicrobial activity}

In the evaluation of the antimicrobial activity of RR-EOs, the preliminary analyses of 32 microorganisms revealed that 20 were sensitive and had varying degrees of inhibition (Figure 4). Rota et al. (2008) noted that the antimicrobial effectiveness of EOs depends on the type of microorganism and classified this effect into three categories of growth inhibition (disk diameter (in $\mathrm{mm}$ ) included): $\geq 20-\mathrm{mm}$ zone indicates strong inhibition; $<20-12-\mathrm{mm}$ zone indicates moderate/mild inhibition and $<12-\mathrm{mm}$ zone indicates no inhibition. Notable sensitivity results include the following microorganisms: sensitive, Streptococcus Group A; intermediate sensitivity, Streptococcus and Bacillus cereus; and the others were resistant. While the extracted EOs from both methods appeared to exert equivalent effects on most of the bacteria, differences were observed for Group A Streptococcus and Salmonella paratyphi B, where MAHD EOs showed a greater antibacterial effect. In contrast, for Salmonella typhi, Staphylococcus epidermidis and Pseudomonas fluorescens, the HD EO exerted greater inhibitory effects. The distinct compositions of the EOs caused by collection season, extraction method or other factors may have determined different antimicrobial or antifungal effects (Falasca et al., 2016; Zantar et al., 2015). Jiao et al. (2012) and Okoh et al. (2010) reported greater antimicrobial activity in EOs obtained by MAHD than by HD. Ajayi et al. (2016) reported that the extraction of certain compounds would be promoted by MAHD. Some research suggests that antimicrobial activity can be influenced by the mixture of compounds that form part of EO rather than by the effects of each individual compound (Deng et al., 2016). The present preliminary study supports the relevance of finding compounds or mixture of compounds with antimicrobial capacities to combat multi-resistant bacteria, such as Pseudomonas, one of the principal opportunistic pathogens in intra-hospital infections, and Staphylococcus aureus, which is known to be virulent and antibiotic-resistant. Moreover, the current results suggest that determining the minimum inhibitory concentration is crucial for establishing the future applications of RR-EOs in economic sectors such as food, cosmetic and pharmaceutical industries.

\section{Energy efficiency of $H D$ and MAHD processes}

Finally, considering that the power level and the mass of grass used for the MAHD method were higher than those used for HD, the energy consumption, the mass of grass required and the process time required to obtain $1 \mathrm{~mL}$ of EO were determined for the selected treatments (treatment 3 for HD and treatment 8 for MAHD). Additionally, the mass of $\mathrm{CO}_{2}$ released into the atmosphere was determined for each of the processes, considering that to obtain $1 \mathrm{kWh}$ from coal or fuel, $800 \mathrm{~g}$ of $\mathrm{CO}_{2}$ will be 


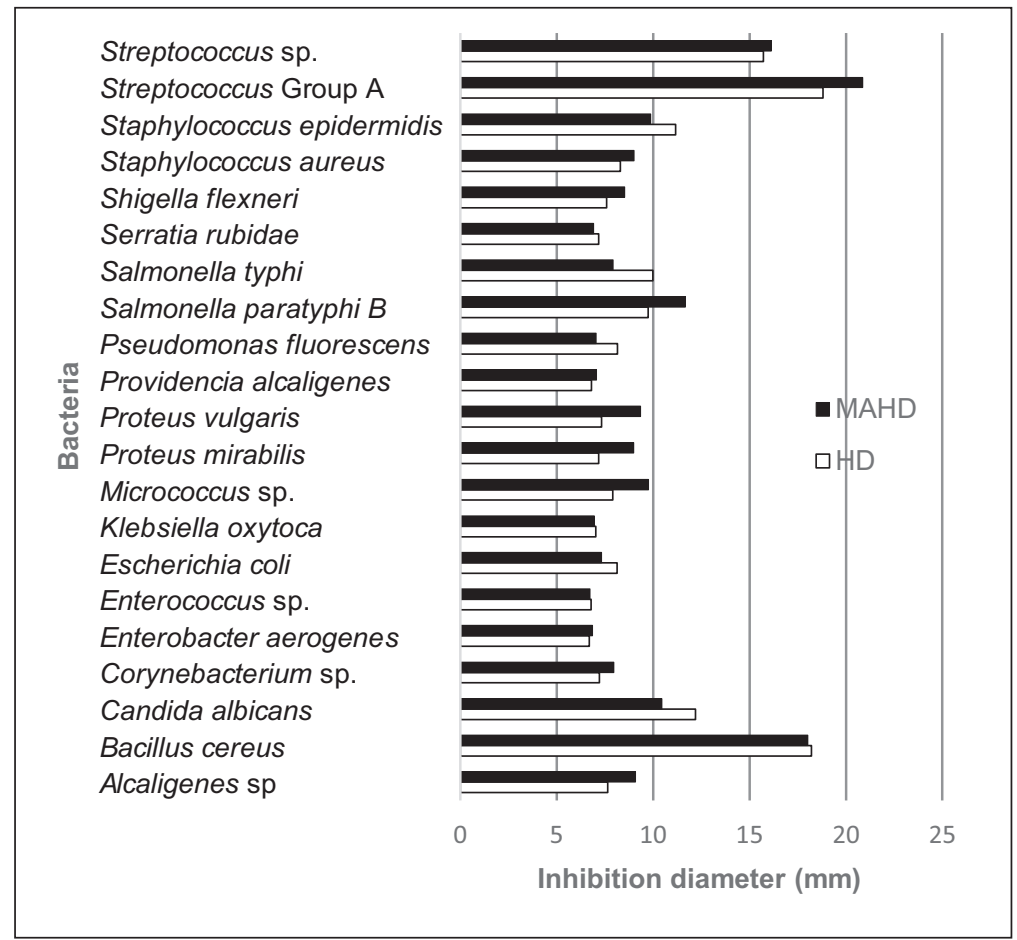

Figure 4. Sensitivity of microorganisms to Rica-Rica essential oil obtained through traditional hydrodistillation (HD) and microwave-assisted HD (MAHD).

rejected in the atmosphere during combustion of fossil fuel (Bernard, 2001, Elyemeni et al., 2019; Ferhat et al., 2006). Table 6 shows the respective data and results, and it was observed that the selected MAHD method $(700 \mathrm{~W}$ and $90 \mathrm{~min}$ ) was $8 \%$ more efficient than the HD method (420 W and $90 \mathrm{~min}$ ) for different calculated parameters. Depending on the harvest season, MAHD requires between 141 and $204 \mathrm{~g}$ of herb compared to 152 to $222 \mathrm{~g}$ required by HD. Similarly, the process time is reduced, which, depending on the harvest season, ranges from 127 to $184 \mathrm{~min}$ for MAHD, in contrast to 136 and $200 \mathrm{~min}$ required by $\mathrm{HD}(420 \mathrm{~W}$ and $150 \mathrm{~g})$. The above is directly related to energy consumption and, consequently, to the estimation of the mass of greenhouse gases, such as $\mathrm{CO}_{2}$, produced during the extraction processes. These results coincide with those found by other authors, who have

Table 6. Comparison of the efficiency of the methods of extraction of essential oils through hydrodistillation and microwave-assisted hydrodistillation, depending on the required mass, process time, energy consumption and estimation of $\mathrm{CO}_{2}$ production.

\begin{tabular}{|c|c|c|c|}
\hline & & $\mathrm{HD}$ (treatment 3) & MAHD (treatment 8) \\
\hline \multirow[t]{6}{*}{ Experimental results } & Extraction time (min) & 90 & 90 \\
\hline & Heating power (W) & 420 & 700 \\
\hline & Sample weight $($ Herb + water) $(\mathrm{g})$ & 1150 & 1200 \\
\hline & Energy density $\left(\mathrm{w} \mathrm{g}^{-1}\right)$ & 0.37 & 0.58 \\
\hline & Yield (mL EO $100 \mathrm{~g}^{-1}$ ) & 0.45 & 0.49 \\
\hline & Electric consumption $(W)^{*}$ & 1000 & 1000 \\
\hline \multirow[t]{4}{*}{ Conditions for $1 \mathrm{~mL}$ EO } & Herb mass required $(\mathrm{g})$ & 222 & 204 \\
\hline & Extraction time (min) & 200 & 184 \\
\hline & Electric consumption (kwh) & 3.33 & 3.06 \\
\hline & $\mathrm{CO}_{2}$ rejected $(\mathrm{kg})$ & 2.67 & 2.45 \\
\hline
\end{tabular}


reported greater energy efficiencies and better environmental impacts of MAHD compared to HD (Golmakani and Moayyedi, 2015; Jeyaratnam et al., 2016; Solanki et $a l ., 2019)$. It is essential to consider energy efficiency and environmental impact together with other characteristics of EOs, such as their composition, presence of fatty acid and biological activity, when evaluating and selecting different extraction techniques and their respective process parameters.

\section{Conclusions}

The activity and fatty acid profile of EOs varied according to the collection season and the extraction method used. The MAHD method $(90 \mathrm{~min}, 700 \mathrm{~W}$ and $200 \mathrm{~g}$ $1000 \mathrm{~mL}^{-1}$ ) resulted in a higher percentage of oil extracted in relation to initial mass, as well as greater antioxidant and antimicrobial capacities, compared to the traditional HD method. However, the traditional HD method (90 min, $420 \mathrm{~W}$ and $150 \mathrm{~g}-1000 \mathrm{~mL}^{-1}$ ) performed better in terms of energy costs and environmental impact. When selecting the extraction method for RR-EO, the yield in relation to the required initial mass, presence of certain fatty acids, antioxidant activity, energy costs and environmental impacts should all be considered carefully. This work shows that the parameters of the processes and extraction technique used significantly affect the performance, energy expenditure, physical and biological characteristics of OEs and their fatty acid profile. Depending on specific requirements related to OEs' potential industrial uses, these parameters are established and the extraction technique selected.

\section{Acknowledgements}

This work was supported by the Universidad de Antofagasta (Proyecto Semilleros 5310) and Workshops for Writing Scientific Articles, Dirección de Gestión de la Investigación, Universidad de Antofagasta.

\section{References}

Ajayi, E.O., Sadimenko, A.P. and Afolayan, A.J., 2016. GC-MS evaluation of Cymbopogon citratus (DC) Stapf oil obtained using modified hydrodistillation and microwave extraction methods. Food Chemistry 209: 262-266. https://doi.org/10.1016/j. foodchem.2016.04.071

Atarés, L. and Chiralt, A., 2016. Essential oils as additives in biodegradable films and coatings for active food packaging. Trends in Food Science \& Technology 48: 51-62. https://doi.org/10.1016/j. tifs.2015.12.001

Benites, J., Bustos, L., Ríos, D., Bravo, F., López, J., Gajardo, S. and Pedro, B., 2013. Antidepressant and anxiolytic-like effects of essential oil from Acantholippia deserticola Phil in female rats. Boletín Latinoamericano y del Caribe de Plantas Medicinales y Aromáticas 12(4): 413-419.

Benites, J., Tello, V., Flores, N., Tapia, D., López, J., Rios, D. and Buc-Calderon, P., 2014. Acantholippia deserticola essential oil as a natural pesticide against agricultural plagues woolly whitefly [Aleurothrixus floccosus (Maskell)], Chilean false red mite (Brevipalpus chilensis Baker) and two-spotted mite (Tetranychus urticae Koch). Boletín Latinoamericano y del Caribe de Plantas Medicinales y Aromáticas 13(3): 297-304.

Bernard J. Le gaz naturel remonte le courant. Sci. Vie. 2001;214: 68-73.

Bhardwaj, S., Passi, S.J., Misra, A., Pant, K.K., Anwar, K., Pandey, R.M. and Kardam, V., 2016. Effect of heating/reheating of fats/oils, as used by Asian Indians, on trans fatty acid formation. Food Chemistry 212: 663-670. https://doi.org/10.1016/j. foodchem.2016.06.021

Bousbia, N., Vian, M.A., Ferhat, M.A., Petitcolas, E., Meklati, B.Y. and Chemat, F., 2009. Comparison of two isolation methods for essential oil from rosemary leaves: hydrodistillation and microwave hydrodiffusion and gravity. Food Chemistry 114(1): 355362. https://doi.org/10.1016/j.foodchem.2008.09.106

Carro, R.T., Isla, M.I., Ríos, J.L., Giner, R.M. and Alberto, M.R., 2015. Anti-inflammatory properties of hydroalcoholic extracts of Argentine Puna plants. Food Research International 67: 230237. https://doi.org/10.1016/j.foodres.2014.11.012

Chemat, F., Vian, M.A. and Cravotto, G., 2012. Green extraction of natural products: concept and principles. International Journal of Molecular Sciences 13(7): 8615-8627. https://doi. org/10.3390/ijms13078615

de Alencar Filho, J.M., Araújo, L., Oliveira, A.P., Guimarães, A.L., Pacheco, A.G., Silva, FRS., Cavalcanti, L., Lucchese, A., Almeida, J.R. and Araújo, E.C.D.C., 2017. Chemical composition and antibacterial activity of essential oil from leaves of Croton heliotropiifolius in different seasons of the year. Revista Brasileira de Farmacognosia 27(4): 440-444. https://doi.org/10.1016/j.bjp.2017.02.004

Delfine, S., Marrelli, M., Conforti, F., Formisano, C., Rigano, D., Menichini, F. and Senatore, F., 2017. Variation of Malva sylvestris essential oil yield, chemical composition and biological activity in response to different environments across Southern Italy. Industrial Crops and Products 98: 29-37. https://doi. org/10.1016/j.indcrop.2017.01.016

Deng, J., He, B., He, D. and Chen, Z., 2016. A potential biopreservative: chemical composition, antibacterial and hemolytic activities of leaves essential oil from Alpinia guinanensis. Industrial Crops and Products 94: 281-287. https://doi.org/10.1016/j. indcrop.2016.09.004

Dhouioui, M., Boulila, A., Chaabane, H., Zina, M.S. and Casabianca, H., 2016. Seasonal changes in essential oil composition of Aristolochia longa L. ssp. paucinervis Batt. (Aristolochiaceae) roots and its antimicrobial activity. Industrial Crops and Products 83: 301-306. https://doi.org/10.1016/j. indcrop.2016.01.025

Díaz-Véliz, G. and Mora, S., 2012. Uso de modelos animales en el estudio de plantas medicinales con propiedades ansiolíticas y antidepresivas. Revista de Farmacología de Chile 5(1): 21. 
El Asbahani, A., Miladi, K., Badri, W., Sala, M., Addi, E.A., Casabianca, H. and Elaissari, A., 2015. Essential oils: from extraction to encapsulation. International Journal of Pharmaceutics 483(1-2): 220-243. https://doi.org/10.1016/j. ijpharm.2014.12.069

Majda Elyemni, M., Louaste, B., Nechad, I., Elkamli, T., Bouia, A., Taleb, M., Chaouch, M., Eloutassi, N., 2019. Extraction of Essential Oils of Rosmarinus officinalis L. by Two Different Methods: Hydrodistillation and Microwave Assisted Hydrodistillation, The Scientific World Journal, 2019, 3659432. https://doi.org/10.1155/2019/3659432

Falasca, A., Caprari, C., De Felice, V., Fortini, P., Saviano, G., Zollo, F. and Iorizzi, M., 2016. GC-MS analysis of the essential oils of Juniperus communis L. berries growing wild in the Molise region: seasonal variability and in vitro antifungal activity. Biochemical Systematics and Ecology 69: 166-175. https://doi. org/10.1016/j.bse.2016.07.026

Falcó, I., Verdeguer, M., Aznar, R., Sánchez, G. and Randazzo, W., 2018. Sanitizing food contact surfaces by the use of essential oils. Innovative Food Science \& Emerging Technologies 51: 220-228. https://doi.org/10.1016/j.ifset.2018.02.013

Fardhyanti, D.S., Sediawan, W.B. and Hisyam, A., 2019. Kinetics of mace (Myristicae arillus) essential oil extraction using microwave-assisted hydrodistillation: effect of microwave power. Industrial Crops and Products 131: 315-322. https://doi. org/10.1016/j.indcrop.2019.01.067

Farhat, A., Benmoussa, H., Bachoual, R., Nasfi, Z., Elfalleh, W., Romdhane, M. and Bouajila, J., 2017. Efficiency of the optimized microwave-assisted extractions on the yield, chemical composition and biological activities of Tunisian Rosmarinus officinalis L. essential oil. Food and Bioproducts Processing 105: 224-233. https://doi.org/10.1016/j.fbp.2017.07.011

FCC, 1996. Food Chemical Codex. 4th ed. Washington, DC: National Academic Press, 413 p.

Ferhat, M.A., Meklati, B.Y., Smadja, J. and Chemat, F., 2006. An improved microwave Clevenger apparatus for distillation of essential oils from orange peel. Journal of Chromatography A 1112(1-2): 121-126. https://doi.org/10.1016/j.chroma.2005. 12.030

Folch, J., Lees, M. and Sloane, G.H., 1957. A simple method for the isolation and purification of total lipids from animal tissues. The Journal Biological Chemistry 226(1): 497-509.

Gadotti, C., Nelson, L. and Diez-Gonzalez, F., 2014. Inhibitory effect of combinations of caprylic acid and nisin on Listeria monocytogenes in queso fresco. Food Microbiology 39: 1-6. https://doi. org/10.1016/j.fm.2013.10.007

Gasparetto, A., Cruz, A.B., Wagner, T.M., Bonomini, T.J., Correa, R. and Malheiros, A., 2017. Seasonal variation in the chemical composition, antimicrobial and mutagenic potential of essential oils from Piper cernuum. Industrial Crops and Products 95: 256-263. https://doi.org/10.1016/j.indcrop.2016.10.030

Gavahian, M., Farahnaky, A., Farhoosh, R., Javidnia, K. and Shahidi, F., 2015. Extraction of essential oils from Mentha piperita using advanced techniques: microwave versus ohmic-assisted hydrodistillation. Food and Bioproducts Processing 94: 50-58. https://doi.org/10.1016/j.fbp.2015.01.003
Golmakani, M.T. and Moayyedi, M., 2015. Comparison of heat and mass transfer of different microwave-assisted extraction methods of essential oil from Citrus limon (Lisbon variety) peel. Food Science \&Nutrition 3(6): 506-518. https://doi.org/10.1002/ fsn 3.240

Hashemi, S.M.B., Khaneghah, A.M., Koubaa, M., Barba, F.J., Abedi, E., Niakousari, M. and Tavakoli, J., 2018. Extraction of essential oil from Aloysia citriodora Palau leaves using continuous and pulsed ultrasound: kinetics, antioxidant activity and antimicrobial properties. Process Biochemistry 65: 197-204. https://doi.org/10.1016/j.procbio.2017.10.020

Jemâa, J.M.B., Haouel, S., Bouaziz, M. and Khouja, M.L., 2012. Seasonal variations in chemical composition and fumigant activity of five Eucalyptus essential oils against three moth pests of stored dates in Tunisia. Journal of Stored Products Research 48: 61-67. https://doi.org/10.1016/j.jspr.2011.10.001

Jeyaratnam, N., Nour, A.H., Kanthasamy, R., Nour, A.H., Yuvaraj, A.R. and Akindoyo, J.O., 2016. Essential oil from Cinnamomum cassia bark through hydrodistillation and advanced microwave-assisted hydrodistillation. Industrial Crops and Products 92: 57-66. https://doi.org/10.1016/j.indcrop.2016. 07.049

Jiao, J., Fu, Y.J., Zu, Y.G., Luo, M., Wang, W., Zhang, L. and Li, J., 2012. Enzyme-assisted microwave hydrodistillation essential oil from Fructus forsythia, chemical constituents, and its antimicrobial and antioxidant activities. Food Chemistry 134(1): 235-243. https://doi.org/10.1016/j.foodchem.2012.02.114.

Koç, M., Gecgel, U., Karasu, S., Tirpanci Sivri, G., Apaydin, D., Gulcu, M. and Ozcan, M.M., 2019. Valorisation of seeds from different grape varieties for protein, mineral, bioactive compounds content, and oil quality. Quality Assurance and Safety of Crops \& Foods 11(4): 351-359. https://doi.org/10.3920/ QAS2018.1507

Kusuma, H.S., Altway, A. and Mahfud, M., 2018. Solvent-free microwave extraction of essential oil from dried patchouli (Pogostemon cablin Benth) leaves. Journal of Industrial and Engineering Chemistry 58: 343-348. https://doi.org/10.1016/j. jiec.2017.09.047

Larrazabal, M.J., Palma, J., Paredes, A., Morales, G. and Mercado, A., 2018. Effect of brewing conditions on pigments and total polyphenols content and biological activities of the Acantholippia deserticola (Phil.) infusion. CyTA-Journal of Food 16(1): 588595. https://doi.org/10.1080/19476337.2018.1441189

Larrazabal-Fuentes, M., Palma, J., Paredes, A, Mercado, A., Neira, I., Lizama, C., Sepulveda, B. and Bravo, J., 2019. Chemical composition, antioxidant capacity, toxicity and antibacterial activity of the essential oils from Acantholippia deserticola (Phil.) Moldenke (Rica rica) and Artemisia copa Phil. (Copa copa) extracted by microwave-assisted hydrodistillation. Industrial Crops and Products 142: 111830. https://doi.org/10.1016/j.indcrop.2019. 111830

Li, X.J., Wang, W., Luo, M., Li, C.Y., Zu, Y.G., Mu, P.S. and Fu, Y.J., 2012. Solvent-free microwave extraction of essential oil from Dryopteris fragrans and evaluation of antioxidant activity. Food Chemistry 133(2): 437-444. https://doi.org/10.1016/j. foodchem.2012.01.056 
Megawati, Fardhyanti, D.S., Sediawan, W.B. and Hisyam, A., 2019. Kinetics of mace (Myristicae arillus) essential oil extraction using microwave assisted hydrodistillation: effect of microwave power. Industrial Crops and Products 131(6): 315-322. https:// doi.org/10.1016/j.indcrop.2019.01.067

Moghaddam, M. and Farhadi, N., 2015. Influence of environmental and genetic factors on resin yield, essential oil content and chemical composition of Ferula assa-foetida L. populations. Journal of Applied Research on Medicinal and Aromatic Plants 2(3): 69-76. https://doi.org/10.1016/j.jarmap.2015.04.001

Morales, G., Paredes, A., Sierra, P. and Loyola, L.A., 2008. Antioxidant activity of $50 \%$ aqueous-ethanol extract from Acantholippia deserticola. Biological Research 41(2): 151-155. https://doi.org/10.4067/S0716-97602008000200004.

Nazarni Che Isa, M., Ajit, A., Naila, A. and Sulaiman, A.Z., 2018. Effect of microwave-assisted hydrodistillation extraction on extracts of Ficus deltoidea. Materials Today: Proceedings 5(10): 21772-21779. https://doi.org/10.1016/j.matpr.2018.07.031

Ohlrogge, J., Thrower, N., Mhaske, V., Stymne, S., Baxter, M., Yang, W., Liu, J., Shaw, K., Shorrosh, B., Zhang, M., Wilkerson, C. and Matthäus, B., 2018. Plant FAdb: a resource for exploring hundreds of plant fatty acid structures synthesized by thousands of plants and their phylogenetic relationships. The Plant Journal 96: 1299-1308. https://doi.org/10.1111/tpj.14102

Okoh, O.O., Sadimenko, A.P. and Afolayan, A.J., 2010. Comparative evaluation of the antibacterial activities of the essential oils of Rosmarinus officinalis L. obtained by hydrodistillation and solvent-free microwave extraction methods. Food Chemistry 120(1): 308-312. https://doi.org/10.1016/j. foodchem.2009.09.084

Olmedo, R.H., Asensio, C.M. and Grosso, N.R., 2015. Thermal stability and antioxidant activity of essential oils from aromatic plants farmed in Argentina. Industrial Crops and Products 69: 21-28. https://doi.org/10.1016/j.indcrop.2015.02.005

Orio, L., Cravotto, G., Binello, A., Pignata, G., Nicola, S. and Chemat, F., 2012. Hydrodistillation and in situ microwave-generated hydrodistillation of fresh and dried mint leaves: a comparison study. Journal of the Science of Food and Agriculture 92(15): 3085-3090. https://doi.org/10.1002/jsfa.5730

Parada, M., 2012. Legislación en Chile sobre fitofármacos y plantas medicinales. Revista de Farmacología de Chile 5(2): 7-11.

Périno-Issartier, S., Ginies, C., Cravotto, G. and Chemat, F., 2013. A comparison of essential oils obtained from lavandin via different extraction processes: ultrasound, microwave, turbohydrodistillation, steam and hydrodistillation. Journal of Chromatography A 1305: 41-47. https://doi.org/10.1016/j.chroma.2013.07.024

Rezaei, F., Jamei, R. and Heidari, R., 2018. Evaluation of volatile profile, fatty acids composition and in vitro bioactivity of Tagetes minuta growing wild in Northern Iran. Advanced Pharmaceutical Bulletin 8(1): 115-121. https://doi. org/10.15171/apb.2018.014

Rodrigues, L.B., Martins, A.O.B.P.B., Cesário, F.R.A.S., Castro, F.F., de Albuquerque, T.R., Fernandes, M.N.M. and Barbosa, R., 2016. Anti-inflammatory and anti-edematogenic activity of the Ocimum basilicum essential oil and its main compound estragole: In vivo mouse models. Chemico-Biological
Interactions $\quad 257: \quad 14-25 . \quad$ https://doi.org/10.1016/j. cbi.2016.07.026

Rojo, L.E., Benites, J., Lopez, J., Rojas, M., Diaz, P., Ordóñez, J. and Pastene, E., 2009. Antioxidant capacity and polyphenolic content of twelve traditionally used herbal medicinal infusions from the South American Andes. Boletín Latinoamericano y del Caribe de Plantas Medicinales y Aromaticas 8: 498-508.

Rojo, L., Benites, J., Rodrigues, A., Venâncio, F., Ramalho, L., Teixeira, A. and Costa, C., 2006. Composition and antimicrobial screening of the essential oil of Acantholippia deserticola (Phil. ex F. Phil.) Moldenke. Journal of Essential Oil Research 18(6): 695-697. https://doi.org/10.1080/10412905.2006.9699209

Rota, M.C., Herrera, A., Martınez, R.M., Sotomayor, J.A. and Jordan, M.J., 2008. Antimicrobial activity and chemical composition of Thymus vulgaris, Thymus zygis and Thymus hyemalis essential oils. Food Control 19: 681-687. https://doi. org/10.1016/j.foodcont.2007.07.007

Ruiz-Rico, M., Fuentes, C., Pérez-Esteve, É., Jiménez-Belenguer, A.I., Quiles, A., Marcos, M.D. and Barat, J.M., 2015. Bactericidal activity of caprylic acid entrapped in mesoporous silica nanoparticles. Food Control 56: 77-85. https://doi.org/10.1016/j. foodcont.2015.03.016

Sá, S.D., Fiuza, T.S., Borges, L.L., Ferreira, H.D., Tresvenzol, L.M., Ferri, P.H. and Paula, J.R., 2016. Chemical composition and seasonal variability of the essential oils of leaves and morphological analysis of Hyptis carpinifolia. Revista Brasileira de Farmacognosia 26(6): 688-693. https://doi.org/10.1016/j.bjp.2016.05.011

Sampietro, D.A., Lizarraga, E.F., Ibatayev, Z.A., Omarova, A.B., Suleimen, Y.M. and Catalán, C.A., 2016. Chemical composition and antimicrobial activity of essential oils from Acantholippia deserticola, Artemisia proceriformis, Achillea micrantha and Libanotis buchtormensis against phytopathogenic bacteria and fungi. Natural Product Research 30(17): 1950-1955. https://doi. org/10.1080/14786419.2015.1091453

Shahsavarpour, M., Lashkarbolooki, M., Eftekhari, M.J. and Esmaeilzadeh, F., 2017. Extraction of essential oils from Mentha spicata L. (Labiatae) via optimized supercritical carbon dioxide process. The Journal of Supercritical Fluids 130: 253-260. https://doi.org/10.1016/j.supflu.2017.02.004

Sodeifian, G. and Sajadian, S.A., 2017. Investigation of essential oil extraction and antioxidant activity of Echinophora platyloba DC using supercritical carbon dioxide. The Journal of Supercritical Fluids 121: 52-62. https://doi.org/10.1016/j. supflu.2016.11.014

Solanki, K., Desai, M. and Parikh, J., 2019. Microwave intensified extraction: a holistic approach for extraction of citronella oil and phenolic compounds. Chemical Engineering and Processing: Process Intensification 146: 1-9. https://doi.org/10.1016/j. cep.2019.107694

Soran, M.L., Cobzac, S.C., Varodi, C., Lung, I., Surducan, E. and Surducan, V., 2009. The extraction and chromatographic determination of the essentials oils from Ocimum basilicum L. by different techniques. Journal of Physics: Conference Series 182(1): 012016. https://doi.org/10.1088/1742-6596/182/1/012016

Stanojević, L.P., Radulović, N.S., Djokić, T.M., Stanković, B.M., Ilić, D.P., Cakić, M.D. and Nikolić, V.D., 2015. The yield, 
composition and hydrodistillation kinetics of the essential oil of dill seeds (Anethi fructus) obtained by different hydrodistillation techniques. Industrial Crops and Products 65: 429-436. https:// doi.org/10.1016/j.indcrop.2014.10.067

Taban, A., Saharkhiz, M.J. and Niakousari, M., 2018. Sweet bay (Laurus nobilis L.) essential oil and its chemical composition, antioxidant activity and leaf micromorphology under different extraction methods. Sustainable Chemistry and Pharmacy 9: 12-18. https://doi.org/10.1016/j.scp.2018.05.001

Tomaino, A., Cimino, F., Zimbalatti, V., Venuti, V., Sulfaro, V., De Pasquale, A. and Saija, A., 2005. Influence of heating on antioxidant activity and the chemical composition of some spice essential oils. Food Chemistry 89(4): 549-554. https://doi. org/10.1016/j.foodchem.2004.03.011

Torrenegra, M.E., Granados, C., Osorio, M.R. and León, G., 2015. Comparación de la Hidro-destilación Asistida por Radiación de Microondas (MWHD) con hidro-destilación convencional (HD) en la extracción de aceite esencial de Minthostachys mollis. Información Tecnológica 26(1): 117-122. https://doi. org/10.4067/S0718-07642015000100013

Torres-León, C., Rojas, R., Serna-Cock, L., Belmares-Cerda, R. and Aguilar, C.N., 2017. Extraction of antioxidants from mango seed kernel: optimization assisted by microwave. Food and Bioproducts Processing 105: 188-196. https://doi.org/10.1016/j. fbp.2017.07.005

Ud-Daula, A.S., Demirci, F., Salim, K.A., Demirci, B., Lim, L.B., Baser, K.H.C. and Ahmad, N., 2016. Chemical composition, antioxidant and antimicrobial activities of essential oils from leaves, aerial stems, basal stems, and rhizomes of Etlingera fimbriobracteata (K. Schum.) R.M. Sm. Industrial Crops and Products 84: 189-198. https://doi.org/10.1016/j.indcrop.2015.12.034.
Valenzuela, A., 2008a. Ácidos grasos con isomería trans I: Su origen y los efectos en la salud humana. Revista chilena de Nutrición 35(3): 162-171. https://doi.org/10.4067/S071775182008000300001

Valenzuela, A., 2008b. Ácidos grasos con isomería Trans II: situación de consumo en Latinoamérica y alternativas para su sustitución. Revista Chilena de Nutrición 35(3): 172-180. https://doi. org/10.4067/S0717-75182008000300001

Yang, Z.H., Miyahara, H. and Hatanaka, A., 2011. Chronic administration of palmitoleic acid reduces insulin resistance and hepatic lipid accumulation in KK-A y mice with genetic type 2 diabetes. Lipids in Health and Disease 10: 120. https://doi. org/10.1186/1476-511X-10-120

Zaïri, A., Nouir, S., Zarrouk, A., Haddad, H., Khélifa, A., Achour, L., Tangy, F., Chaouachi, M. and Trabelsi, M., 2019. Chemical composition, fatty acids profile and biological properties of Thymus capitatus (L.) Hoffmanns, essential Oil. Scientific Report 9: 20134. https://doi.org/10.1038/s41598-019-56580-y

Zantar, S., Haouzi, R., Chabbi, M., Laglaoui, A., Mouhib, M., Boujnah, M. and Zerrouk, M.H., 2015. Effect of gamma irradiation on chemical composition, antimicrobial and antioxidant activities of Thymus vulgaris and Mentha pulegium essential oils. Radiation Physics and Chemistry 115: 6-11. https://doi. org/10.1016/j.radphyschem.2015.05.019

Zarria, K., Gajardo, S., Benites, J., López, J. and Rojas, M., 2010. Formulación y evaluación de la estabilidad de una serie de vehículos, para el desarrollo de un biopesticida a base de aceite esencial de Acantholippia deserticola. Revista del Colegio de Bioquímica y Farmacia de Bolivia (BIOFARBO) 18(2): 20-30. 